\title{
DORUČOVÁNÍ PÍSEMNOSTÍ \\ A ELEKTRONICKÝ PRÁVNÍ STYK V PRACOVNĚPRÁVNÍCH VZTAZÍCH
}

\author{
JÁN MATEJKA*
}

Abstrakt: Delivery of documents and electronic communication in labour law relations

The current legal framework for contracting in labour law is certainly traditional and in the spirit of fundamental labour law principles sufficiently protective. In terms of modern, flexible or other standard forms of electronic legal relations it must also be critically examined as the wide application of protection regulation is usually an obstacle to further development of modern forms of legal relations. The development of the information society presupposes an effective, legally permitted and demonstrably reliable tool enabling an efficient electronic legal contact and archiving of related electronic records. It is precisely electronic documents that form the dominant part of the most standard contractual processes including labour law. The simplicity, quickness, ergonomics and overall efficiency of these tools not only lead to the use of electronic documents more often than paper documents, but also to the fact that electronic documents are used where traditional forms of legal action based on documentary record have been used. The purpose of this article is to offer a certain perspective and to stimulate a discussion on the issue of the current construction of the implementation of electronic written legal proceedings in labour law based on a certain mandatory limitation that "if the legal action has not been delivered, it does not exist" in favour of the related, although at the same time contradictory but civilistic, in many respects, more appropriate thesis, according to which it must be delivered to the sphere of disposition of the other contracting party.

Keywords: delivery; documents; labour law relatons; flexibility; e-signature; formal requirements; proofs; e-documents; reliability of proof

Klíčová slova: doručování; písemnost; pracovněprávní vztah; flexibilita; elektronický podpis; formální náležitosti; prokazování; elektronický dokument; důkazní spolehlivost

DOI: $10.14712 / 23366478.2019 .5$

* Autor působí na Ústavu státu a práva Akademie věd ČR, v. v. i. a na Matematicko-fyzikální fakultě Univerzity Karlovy, je též advokátem v Praze. Příspěvek vznikl za podpory projektu Grantové agentury České republiky č. 16-26910S s názvem Biometrické údaje a jejich zvláštní právní ochrana (Biometric Data and Their Specific Legal Protection). 


\section{1. ÚVODEM K DORUČOVÁNÍ PRACOVNĚPRÁVNÍCH PÍSEMNOSTÍ}

V pracovněprávních vztazích již tradičně platí, že projev vůle vyvolává sledované právní následky jen tehdy, pokud byl doručen relevantním subjektům pracovněprávního vztahu ${ }^{1}$; účinky těchto právních jednání jsou tak podmíněny dodržením relativně striktního formálně-procesního postupu spočívající v řádném doručení, jehož podrobná úprava je včleněna do části třinácté zákoníku práce, konkrétně pak ustanovení §334-337. Svou podstatou tak jde o úpravu speciální, nebot'v obecné rovině občanský zákoník pravidla tohoto typu neobsahuje. Tato úprava tak vychází jak z existujících pracovněprávních zásad, zejména pak ochranné funkce, tak i z existující praxe a relativně ustálené judikatury.

Bez ohledu na konkrétní formu právního jednání tak zákoník práce upravuje, kromě obecných ustanovení o doručování zaměstnavatelem (§ 334), také tři samostatné způsoby doručování písemností zaměstnavatele zaměstnanci, a to:

- osobní doručení zaměstnavatelem ve smyslu ustanovení $§ 334$ odst. 2 (ve spojení s odst. 3 zákoníku práce);

- doručování prostřednictvím sítě nebo služby elektronických komunikací, tedy zpravidla cestou elektronické pošty ve smyslu ustanovení § 335 zákoníku práce;

- doručování prostřednictvím provozovatele poštovních služeb (ve smyslu § 336 ve spojení s § 334 odst. 4).

$\mathrm{Z}$ uvedeného výčtu je zřejmé, že pracovněprávní úprava preferuje osobní doručení př́mo zaměstnavatelem, resp. pověřeným zástupcem zaměstnavatele, před ostatními způsoby doručování. ${ }^{2}$ Jakkoliv je zde patrná určitá snaha zákonodárce o jistou komplexnost, resp. uzavřenost všech těchto způsobů doručování, je zřejmé, že zde uvedené způsoby doručování nejsou popsány s rovnoměrnou mírou detailu, jasnosti a zejména přesností zpracování; v některých aspektech tak nutno důsledně zvážit, zda a pokud ano, tak do jaké míry lze tyto způsoby doručování rozšiřovat o jiné související formy realizované v mezích a na základě této speciální právní úpravy. Př́íkladem hodným takové zvláštní úvahy je doručování resp. realizace elektronických písemností, jež bude dále předmětem tohoto článku.

Samotný zákoník práce s pojmem elektronická písemnost výslovně nepracuje, upravuje pouze obecně doručování prostřednictvím sítě nebo služby elektronických komunikací, a to bud' zaměstnanci (§ 335) nebo zaměstnavateli (\$337); s ohledem na definiční podstatu ${ }^{3}$ služeb či sítí elektronických komunikací. Lze dovodit, že takto lze doručit

1 K tomu více viz např. DRÁPAL, L. § 334 [Obecné ustanovení o doručování zaměstnavatelem]. In: BĚLINA, M. - DRÁPAL, L. - BĚLINA, T. - BOGNÁROVÁ, V. - DOLEŽÍLEK, J. - NOVOTNÝ, Z. PICHRT, J. - PUTNA, M. - ROTHOVÁ, E. - STÁDNÍK, J. - ŠTEFKO, M. Zákoník práce. 2. vyd. Praha: Nakladatelství C. H. Beck, 2015, s. 1361. ISBN 978-80-7400-290-8.

$2 \mathrm{~K}$ tomu srovnej celkový kontext a účel ustanovení $§ 334$ odst. 2 zákoníku práce.

3 K tomu viz ustanovení § 2 zákona č. 127/2005 Sb., zákona o elektronických komunikacích, ve znění pozdějších předpisů. 
pouze elektronickou písemnost. Na doručování písemností touto cestou klade zákoník práce poměrně prrísné podmínky, a to ( $\mathrm{v}$ př́ípadě doručování zaměstnanci $\left.{ }^{4}\right)$ :

- písemný souhlas zaměstnance,

- poskytnutí elektronické adresy pro doručování ze strany zaměstnance,

- opatření doručované písemnosti uznávaným elektronickým podpisem zaměstnavatele ${ }^{5}$,

- potvrzení zaměstnance o přijetí doručované písemnosti, které zaměstnanec opatří svým uznávaným elektronickým podpisem nikoliv později než do 3 dnů od odeslání písemnosti.

Účinky takto doručovaných písemností tak nastanou až po dodržení shora uvedeného formálně-procesního postupu, $\mathrm{v}$ opačných př́padech půjde o jednání neúčinné. Takto striktní požadavek zákonodárce klade na smluvní strany velmi vysoké požadavky, což ve svém důsledku zpravidla vede jednak k nevyužívání této možnosti (s důvodů své celkové komplikovanosti a obtížné splnitelnosti), př́ípadně k samotnému ohrožení všech budoucích účinků tohoto jednání (v př́ípadě jejich nedůsledného použití); nehledě pak na skutečnost, že úprava tak ve svém důsledku téměř eliminuje většinu efektů komunikace $v$ elektronické podobě mezi smluvními stranami, čímž ve svém důsledku dochází k ohrožení celkového elektronického pracovněprávního styku.

Předmětná úprava však trpí ještě jedním nedostatkem, navzdory své relativní komplexnosti totiž nepočitá $\mathrm{s}$ tím, že by elektronické pracovněprávní písemnosti mohly být doručovány (či přesněji realizovány) i jiným způsobem než jen prostřednictvím služby či sítě elektronických komunikací, a to napřr. vytvořením (generováním) a vzájemným předáním elektronické písemnosti přímo $\mathrm{v}$ místě sídla zaměstnavatele, tedy jakýmsi doručením elektronické písemnosti svého druhu (formou osobního předání).

Absence této výslovné možnosti realizace právních jednání patrně nepředstavuje nic jiného než projev ochranné funkce pracovního práva, nicméně ve svém důsledku zde nedochází k ochraně slabší stranu pracovněprávního vztahu, ale spíše naopak, k výraznému omezení možností efektivní elektronické komunikace, a to včetně možnosti garance důkazní spolehlivosti elektronických dokumentů, která mohou poskytovat kvalitativně výrazně vyšší důkazní jistotu než tradičně využívané vlastnoručně podepisované listiny. Zákoník práce tak připravuje své adresáty (včetně chráněného zaměstnance) o celou řadu v soukromém právu již využívaných možností, jejichž použití přináší celou řadu výhod, jež v mnoha ohledech mohou vyvážit existující rizika.

V tomto ohledu je proto nezbytné připomenout některé existující možnosti realizace soukromoprávních písemností, a to včetně vybraných aspektů vyplývajících z práva Evropské unie, případně současného občanského zákoníku, včetně tradičního podpisu soukromých písemnosti, resp. určité jeho elektronické alternativy jako svého druhu elektronické obálky v podobě podpisu elektronického, a některých souvisejících as-

4 Konstrukce doručování zaměstnavateli je dle § 337 v zásadě obdobné, nicméně zákoník práce předpokládá určitá méně významná specifika (viz např. možnost elektronického pečetění dle §337 odst. 3 zákoníku práce, apod.)

5 Dle $\S 6$ odst. 2 a $\S 9$ odst. 2 zákona č. 297/2016 Sb., o službách vytvářejících důvěru pro elektronické transakce, ve znění pozdějších předpisů. 
pektů týkajících se vyvratitelné právní domněnky spolehlivosti záznamů o právních jednáních obsažených v elektronickém systému.

Řešení těchto problémů je nutno hledat nejenom v ustálené praxi, ale především v analýze souvisejících ustanovení české i evropské právní úpravy, konkrétně pak v nařízení Evropského Parlamentu a Rady (EU) č. 910/2014 o elektronické identifikaci a službách vytvářejících důvěru pro elektronické transakce na vnitřním trhu (dále jen nařízení eIDAS), v zákoně č. 297/2016 Sb., o službách vytvářejících důvěru v elektronických transakcích, ve znění pozdějších předpisů (dále jen ZoSVD), tak i v ustanovení zákona č. 89/2012 Sb., občanského zákoníku.

\section{TRADIČNÍ VÝZNAM PODPISU NA SOUKROMÝCH LISTINÁCH}

O tradičním významu podpisu v soukromoprávních vztazích toho bylo napsáno relativně mnoho ${ }^{6}$, podpis totiž ve všech jeho heterogenních podobách představoval určitou součást většiny významných aktů realizovaných ve společenském, kulturním či právním styku. Samotný význam podpisu se však v historickém ${ }^{7}$ i současném ${ }^{8}$ kontextu konzistentně opírá zejména o pevný normativní fakt, že podpis jednající osoby je předpokladem platnosti písemných právních jednání (typicky smluv, deklarací, apod.). Tento základní význam podpisu písemné formy právních jednání pak tvoří samotnou normativní podstatu podpisu pro soukromoprávní vztahy, a to včetně vztahů obchodních či pracovních. U veřejnoprávních úkonů jako je např. podání vůči státu, apod., však platí zcela jiné podmínky. Tato dichotomie režimu soukromoprávních a veřejnoprávních úkonů je kromě zjevných historických důvodů způsobena především rozdílem v podstatě těchto vztahů, jakož i v nerovnosti jejich jednotlivých subjektů (k tomu viz níže).

$\mathrm{V}$ dnešním současném pojetí však podpis navenek osvědčuje, resp. stvrzuje určitý akt, typicky právní jednání (např. uzavření smlouvy, potvrzení nějaké skutečnosti, projev vůle osoby, apod.). Písemná forma právního jednání tedy kromě jiných obecných náležitostí ${ }^{9}$ vyžaduje, aby byl př́ílušný projev vůle zachycen na médiu, které má

6 Viz např. ELIÁŠ, K. Právní úkony na soukromých listinách se zvláštním zretelem k jejich podepisování. AD NOTAM, 1996, č. 3, s. 53; MATEJKA, J. Úprava elektronického podpisu v právním řádu ČR, Právník, 2001, 4, 5, s. 582-611; MATEJKA, J. K využití elektronického podpisu v pracovněprávních vztazích, Právo a zaměstnání, 2001, 4. 5, s. 5-11; MATEJKA, J. Vybrané právní překážky elektronického obchodu, Parlamentní zpravodaj, 2002, 4. 3, s. 12-13; případně novější práce KORBEL, F. - MELZER, F. Písemnost, elektronický a biometrický podpis v elektronickém právním jednání, Bulletin advokacie, 2014, 4. 12, s. 31, apod.

7 Viz již neplatný § 40 odst. 3 zákona č. 40/1964 Sb., občanského zákoníku.

8 Uvedená konstatace vyplývá z ustanovení § 561 odst. 1 zákona č. 89/2012 Sb., občanského zákoníku, jež, ve své podstatě přejímá předchozí úpravu z roku 1964, kdy právní jednání bude učiněno v písemné formě za splnění dvou základních předpokladů, kterými jsou písemnost a podpis jednajícího.

9 Jako např. svoboda, vážnost, určitost a srozumitelnost právního úkonu, včetně právně způsobilého subjektu, apod.

Dále pro úplnost nutno zohlednit rovněž problematiku právního jednání vůči „nepřítomnému“ zaměstnanci, jež není v současné pracovněprávní úpravě rovněž dostatečně komplexně řešena, resp. poskytuje př́lišs velký prostor pro př́ipadné zneužití práv zaměstnance, resp. přesněji ochranné funkce (na úkor funkce organizační). Určitou rozumnou inspirací by v tomto ohledu mohla být, byt' i jen částečná, aplikace usta- 
a) právní povahu písemnosti (listiny) a dále pak b) aby byl tento projev vůle podepsán. Uvedené však platí výlučně pro vztahy soukromoprávní (vymezené zejména občanským zákoníkem), o poznání jiný režim je pak dán např. režimem zákoníku práce, který obsahuje relativně zvláštní právní úpravu, zcela jiný je pak režim veřejnoprávních předpisů upravujících komunikaci s orgány veřejné moci.

Jak ostatně vyplývá z výše uvedeného, jako velmi podstatné se zdá být doktrinálně vhodné vymezení pojmu písemnost (resp. listina) a podpis. O tom, co je listina v právním slova smyslu, neobsahuje náš právní řád jedinou výslovnou zmínku. Řada zákonných ustanovení však o listině poměrně často hovoří. Legální definice listiny ale v platné právní úpravě obsažena není. Právní jednání tak musí být zachyceno písemně na jakémkoliv hmotném či nehmotném nosiči, přičemž pro platnost právního jednání není rozhodné, jaké písmo či jazyk byl použit. Co se náležitostí na formu právního jednání týče, je nutno souhlasit s tradiční právní doktrínou ${ }^{10}$, že nejde o vytýkatelný nedostatek právní úpravy, a že je tento problém řešitelný vcelku úspěšně teoreticky. Literatura i praxe se navíc shodly, že za listinu lze považovat (kromě běžných listin papírových) jakékoliv jiné hmotné médium, (např. kůra, kámen či hliněná tabulka) na něž lze zachytit písemný projev, př́p. cokoliv jiného, na čem může být písmo zachyceno s tím, že je lhostejno, ,na jaké látce a jakou látkou“11 je projev vůle sepsán (tedy např. text zachycený rytbou na bronzovou sochu, příp. v písku na písečné pláži či na zahrádce z květin). Obecně lze tedy konstatovat, že listinou, resp. písemností se v našem právním řádu tedy rozumí cokoliv psaného. Dále je zde třeba souhlasit s ustáleným názorem právní praxe, ${ }^{12}$ podle které ,teoretické spory kolem listiny nemaji praktického významu“. ${ }^{13}$

Písemná forma právního úkonu tak nepředpokládá pouhé zachycení obsahu právního jednání v textu listiny (písemnosti), ale dále také existenci podpisu.). Obdobně, jak je tomu v prŕípadě pojmu „listina“, neobsahuje náš právní rád legální definici pojmu ,podpis“. To však již může přinášet řadu jak praktických tak i teoretických problémů. Jednak není př́iliš jasné, jak úplný podpis je z hlediska práva ještě dostatečný a jaký již nikoliv. Nejenom, že není zdaleka zrrejmé, zda postačuje podpis typu „Váš otec“, příp. „Tvůj bratr “, ale ani nelze zcela jednoznačně odpovědět na otázku, zda postačuje stro-

novení § 570 občanského zákoníku upravující právní jednání působí vůči nepřítomné osobě. Současná judikatura Nejvyššího soudu však jde, zdá se, jinou cestou, když v tomto ohledu navíc relativně striktně ve smyslu netriviální úpravy v zákoníku práce dovozuje, že „Pro posouzení, zda v konkrétním prípadě nebylo možné, aby zaměstnavatel písemnost určenou do vlastních rukou doručil zaměstnanci sám, tak může soud přihlédnout např́klad $k$ tomu, zda zaměstnanec byl vůbec (objektivné) prostředky zaméstnavatele dosažitelný, zda zaméstnavatel takový pokus učinil, co bylo důvodem př́padně neúspěšného doručení, zda mélo nějaký smysl učinit dalši pokus o doručení, jak naléhavé bylo doručení písemnosti, zda bylo možné očekávat, že doručení prostřednictvím provozovatele poštovních služeb bude úspěšnější, než opakované doručováni zaměstnavatelem apod." (viz. rozsudek Nejvyššího soudu ze dne 7. 11. 2018, sp. zn. 21 Cdo 2036/2017, ECLI:CZ:NS:2018:21.CDO.2036.2017.1.).

10 ELIÁŠ, K. Právní úkony na soukromých listinách se zvláštním zrretelem k jejich podepisování. AD NOTAM, 1996, č. 3, s. 53.

11 KRČMÁR̆, J. Právo občanské, dil V. - Právo dědické. Praha: Všehrad, 1930, s. 22.

12 Viz např. BUREŠ, J. - DRÁPAL, L. Občanský soudní řád. Komentářr. Praha: C. H. Beck, 1996, s. 61.

13 Nutno však v tomto směru podotknout, že písemná forma právního úkonu může podmiňovat platnost právního úkonu, nikoliv však jeho dokazatelnost. Dojde-li proto ke ztrátě či zničení listiny, není vyloučeno domáhat se nároků z tohoto právního úkonu. Lze-li ovšem tento právní úkon i splnění formy dokázat jinak (např. jinou listinou, svědecky, znalecky, apod.). Neexistence listiny v čase tak pouze oslabuje důkazní pozici (prokazatelnost), nikoliv však př́mo platnost. 
jový či jinak mechanicky na listině vytištěný podpis (řetězec znaků), příp. vlastnoruční podpis (např. zcela nečitelný klikyhák, resp. pouhé iniciále p), či zda je třeba uvést skutečné a úplné jméno tak, jak je zapsáno v matrice a osobních dokladech jednající osoby (tedy nejenom včetně jména a príijmení, ale také i titulů, případně bydliště, rodného čísla, apod.). Při hledání odpovědi nutno přihlédnout k účelu, resp. funkci podpisu. Nečitelnost podpisu by totiž v obecné rovině neměla mít na splnění zákonného požadavek podepsat písemné právní jednání žádný vliv. Podpis v tomto ohledu neplní primárně funkce identifikační, ale zejména stvrzovací, kde stvrzuje skutečnost, že podepisující osoba je vázána svým jednáním, a to právě od okamžiku podpisu. V tomto ohledu lze zcela jistě připustit i uvedení pseudonymu za předpokladu, že to bude známý pseudonym umožňující určení jednající osoby.

S absence právní definice podpisu se vyrovnala právní doktrína, která za podpis na soukromých listinách zpravidla považuje uvedení jména a př́jmení na konci textu právního jednání. ${ }^{14}$ I takováto pravidlo má však své výjimky (viz např. tradice podepisování advokátních písemností na první straně listin, apod.). Pro naplnění požadavku podpisu tak zpravidla postačuje uvedení pouze jména, příjmení. Obecně lze setrvat na požadavku, že je zásadě nutný podpis vlastnoruční (bez ohledu na to, zda je i celé právní jednání učiněno vlastnoručně, či např. sepsáno v textovém editoru. Nutno totiž zohlednit také další funkce podpisu, zejména pak označovací (tj. označení toho, kdo právní jednání činí), jakož i podpůrně funkci identifikační, resp. důkazní, tj. umožnění ověrit identitu podepisující osoby.

S tím ale velmi úzce souvisí i jednotlivé skupiny (kategorie) podpisu užívané v našem právním řádu. Vyjma některých (v mnoha ohledech zjevně překladových nesrovnalostí1 ${ }^{15}$ ) lze totiž ze (striktně) právního hlediska rozlišovat podpis ${ }^{16}$, vlastnoruční podpis ${ }^{17}$, ověřený podpis (at' již soudně, notářsky nebo úředně, případně advokátem) ${ }^{18}$, elektronický podpis (včetně jeho vyšších forem), další hybridní formy podpisu (biometrický podpis, apod.).

\section{PODPIS ELEKTRONICKÝCH PÍSEMNOSTÍ (PRÁVNÍCH JEDNÁNÍ)}

Zákoník práce obsahuje zvláštní právní úpravu právních jednání v ustanovení § 18-20; nejde však o úpravu komplexní, a tedy se subsidiárně použije občanský

14 LAVICKÝ, P. a kol. Občanský zákonik I. Obecná část (§ 1-654). Komentář. 1. vyd. Praha: C. H. Beck, 2014, s. 2022.

15 Jde zejména o pojmy „vlastní podpis“, „podpis vlastní rukou“ (např. čl. 3 odst. 1 sdělení č. 179/1996 Sb.), které považuji s ohledem na dikci jednotlivých ustanovení za synonymické pojmu „vlastnoruční podpis“. Dále s ohledem na § 74 zákona č. 358/1992 Sb. za variantu podpisu nepovažuji „podpis na listině, který osoba uznala za vlastní“ či jiné jeho obdoby. Ověřením podpisu totiž podpis, resp. jeho listina ztrácí část svého jinak ryze soukromoprávního charakteru, přičemž pak plní jiný účel, resp. funkci.

16 Pojem „podpis“ se dle informačního systému Codexis (bez dalších adjektiv) vyskytuje v našem právním rrádu ve více jak 1500 dokumentech v počtu větším než 4500 výrazů (z toho však více jak 1000 výrazů se nachází ve necelých 300 zákonných předpisech).

17 Pojem „vlastnoruční podpis“ již bývá zákonodárcem výslovně užíván velmi zř́́dka. Lze hovořit pouze o několika desítkách výrazů.

18 Viz např. zákon č. 358/1992 Sb., o notářích a jejich činnosti (dále jen notářský řád), v platném znění. 
zákoník, který je tradičně postaven tradičně na relativně neměnných právních principech stanovících určité mantinely, jež jsou ve svém důsledku omezující jak samotného zákonodárce, tak i pro př́ípustný interpretačně-aplikační rozsah právní úpravy. Mezi takovéto principy bezesporu patří zásada dispozitity právní úpravy a princip právní jistoty, včetně na tuto zásadu navazujících postulátů jako je zákaz retroaktivity, ochrana nabytých práv, předvídatelnost rozhodování apod. Oba tyto principy jsou důsledně reflektovány v ustanovení § 559-564 občanského zákoníku upravující formy právního jednání, a to včetně tzv. elektronických právních jednání jako specifických písemností realizovaných elektronickými prostředky, včetně požadavku na jejich podpis.

Právní jednání může mít v zásadě libovolnou formu, není-li zákonem vyžadována forma písemná (§ 559 občanského zákoníku an.), a to zpravidla tam, kde to vyžaduje jeho význam a povaha. V tomto ohledu tak lze rozlišovat právní jednání neformální, jejichž formu zákon neupravuje, a právní jednání formální, tj. ta, pro která je zákonem předepsána určitá (zpravidla písemná) forma, jež tak současně plní určitou varující funkci. Nedodržení takto stanovené formy může mít za následek relativní ${ }^{19} \mathrm{i}$ absolutní ${ }^{20}$ neplatnost právního jednání ${ }^{21}$, nikoliv však ve všech př́padech; soudní praxe následky neplatnosti omezuje zpravidla na případy, pokud to smysl a účel zákona vyžaduje (NS 29 Cdo 3919/2014).

Je-li zákonem vyžadována písemná forma ${ }^{22}$, stanoví dále zákon, že k platnosti takového jednání ( $\mathrm{tj}$. učiněného v písemné formě) se vyžaduje podpis jednajícího, přičemž dále blanketovou právní normou odkazuje na jiný právní předpis, který stanoví, jak lze při právním jednání učiněném elektronickými prostředky písemnost elektronicky podepsat (§ 561 odst. 1občanského zákoníku). Takovýmto právním předpisem je především ZoSVD, který je tzv. adaptačním předpisem k nařízení eIDAS. V př́ípadě elektronických právních jednání tak je požadavek písemné formy naplněn tak, že k obsahu tohoto jednání bude připojen elektronický podpis ve smyslu ZoSVD.

Platná právní úprava však připouští i výjimku z výše uvedeného pravidla o požadavku podpisu písemného právního jednání. Z ustanovení § 562 odst. 2 občanského

19 Zejména pak v situacích, kdy je zákonný požadavek na právní formu stanoven pouze na ochranu zájmu určité osoby, tj. plní v zásadě pouze varující funkci pro účastníky takovéhoto jednání (§ 586 občanského zákoníku).

20 Zejména pak v situacích, kde se zvolená forma jeví jako př́íćíí se dobrým mravům, anebo které odporuje zákonu a zjevně narušuje veřejný pořádek (§ 588 občanského zákoníku). Absolutní neplatnost tak bude namístě zejména tehdy, kdy požadavek formy neplní pouze funkci varující, ale zejména zajištovací ve prospěch třetích stran nebo ve veřejném zájmu - viz např. převod věcného práva k nemovité věci dle $\S 560$ občanského zákoníku), apod.

21 Hovoříme tak o náležitosti právního jednání ve smyslu ustanovení $§ 545$ občanského zákoníku. Předepsaná forma by měla být $\mathrm{v}$ zásadě dodržena $\mathrm{k}$ celému právnímu jednání, judikatura nicméně nevylučuje, aby části právního jednání byly učiněny v různých formách. K tomu srovnej rozhodnutí NS 29 Odo 14/2001, prípadně NS 2 Odon 76/97.

22 Povinnost písemné formy může být uložena zákonem, nebo předchozí vzájemnou dohodou stran (§559 o. z.). Bez jejího uložení lze jednat elektronicky jakýmkoli způsobem, i bez elektronického podpisu vůbec. K volbě formy nelze nikoho nutit, a to ani k jejímu přijímání (opět § 559 o. z.). Právním jednáním učiněným elektronickými prostředky zatím nelze podle práva ČR provést jednání, která u vlastnoručního podpisu vyžadují ověření podpisu třetí stranou (úřední ověření). Nelze jím provést ani taková právní jednání, u kterých zákon stanoví více náležitostí než jen písemnou formu, např. požadavek napsání závěti vlastní rukou podle §1533občanského zákoníku. K tomu více KMENT, V. Nahradí elektronický podpis prostý ten tradiční vlastnoruční? In: Bulletin advokacie. Roč. 2016, č. 12, s. 5. 
zákoníku vyplývá, že písemná forma je zachována u právních jednání učiněných elektronickými nebo jinými technickými prostředky, jež umožňují zachycení jeho obsahu a určení jednající osoby, a to zcela bez ohledu, zda byly podepsány či nikoliv. Jde tak o zvláštní úpravu elektronické písemnosti bez podpisu (lex specialis ${ }^{23}$ ve vztahu k § 561 odst. 1 občanského zákoníku), které zákon přiznává právní účinky písemnosti za předpokladu, že jde o písemnost způsobilou zachytit obsah tohoto jednání a určit, resp. identifikovat jednající osobu. ${ }^{24}$ Zákon tak sice výslovně podpis pro tyto jiné formy nestanoví, nicméně stanoví v zásadě obdobný požadavek identifikace jednající osoby, což lze považovat za svého druhu zákonnou alternativu podpisu, jehož účelem i hlavní funkcí je zpravidla právě identifikace; $v$ tomto ohledu tak lze soudit, že tento požadavek „identifikace“ může být naplněn např. nějakým biometrickým či jiným obdobným identifikátorem, který sice stricto sensu nepředstavuje podpis v právním smyslu, nicméně plní zpravidla obdobný účel i funkci. Uvedené pojetí tak reflektuje jak autonomii vůle stran v soukromém právu, tak zároveň i představuje krok směrem k rozšiřování elektronické kontraktace i právního styku. ${ }^{25}$

Jak již bylo zmíněno výše, pro elektronická právní jednání stanoví občanský zákoník podmínku připojení elektronického podpisu ve smyslu ZoSVD, který představuje jediný právní předpis, který stanoví, jak lze takovouto písemnost podepsat. Ustanovení $\S 5$ a násl. ZoSVD pak upravuje druhy podepisování v závislosti na podepisujícím subjektu, resp. jeho veřejnoprávní povaze, jakož i jednotlivé právně př́pustné druhy elektronického podpisu upravené v eIDAS. Z $\$ 7$ tohoto zákona pak jednoznačně vyplývá, že $\mathrm{k}$,podepisování elektronickým podpisem lze použit zaručený elektronický podpis, uznávaný elektronický podpis, př́padně jiný typ ${ }^{26}$ elektronického podpisu, podepisuje-li se elektronický dokument, kterým se právně jedná jiným způsobem než způsobem uvedeným v § 5 nebo § 6 odst. 1.“. Za tzv. ,jiný typ elektronického podpisu“ ve smyslu tohoto ustanovení nutno považovat i základní (prostý) elektronický podpis dle eIDAS, prričemž ,jiným způsobem“ je pak právě právní jednání ve smyslu občanského zákoníku, tj. typicky podepisování soukromých elektronických písemnosti. Z platné právní

23 K obdobnému závěru dochází též komentářová literatura MELZER, F. - TÉGL, P. a kol. Občanský zákonik - velký komentár̆. Svazek III., s. 637, případně i ŠVESTKA a kol., s. 1387, př́ípadně též PETROV, VYTISK a kol., s. 597.

24 Jako problematické se v tomto smyslu nicméně jeví ustanovení § 3026 odst. 1občanského zákoníku, které stanoví, že nevylučuje-li to povaha písemnosti, platí ustanovení tohoto zákona o listině obdobně i pro jinou písemnost bez zřetele na její podobu. Uvedené ustanovené tak výslovně připouští použití analogie těch zákonných ustanovení upravujících formu listiny i pro jiné formy písemností, tedy včetně písemností elektronických i jiných textů nepřenositelných na hmotných nosičích, apod. Vzniká tak otázka, zda i na pro formy elektronické písemnosti bez podpisu ve smyslu ustanovení § 561 odst. 1občanského zákoníku nepožadovat podpis (per analogiam).

25 V souvislosti s výše uvedeným nutno zmínit i navazující ustanovení § 562 odst. 2občanského zákoníku upravující tzv. domněnku spolehlivosti elektronických záznamů stanovící, že záznamy údajů o právních jednáních v elektronickém systému jsou spolehlivé, provádějí-li se systematicky a posloupně a jsou-li chráněny proti změnám. Byl-li záznam pořízen při provozu závodu a dovolá-li se jej druhá strana k svému prospěchu, má se za to, že záznam je spolehlivý.

${ }^{26}$ Za výjimky v tomto smyslu zákon považuje pouze jednání státu, resp. jeho organizačních složek a dalších veřejnoprávních podepisujících podle $\S 5$ odst. 1 ZoSVD, jež vyžaduje kvalifikovaný elektronický podpis ve smyslu eIDAS. 
úpravy tak vyplývá, že v soukromoprávních vztazích postačit pro splnění formálních náležitostí v zásadě jakýkoliv typ elektronického podpisu dle eIDAS.

Nahlédneme-li do př́islušných ustanovení eIDAS, zjistíme, že základní forma elektronického podpisu je vymezena v ustanovení čl. 3 odst. 10, který stanoví, že elektronickým podpisem jsou:

- data v elektronické podobé,

- která jsou připojena k jiným datům v elektronické podobě nebo jsou s nimi logicky spojena a

- která podepisující osoba použivá k podepsání.

Prostou analýzou výše uvedeného vymezení lze dojít k závěru, že předmětné vymezující ustanovení neobsahuje samo o sobě jakékoliv kvalitativní požadavky směrem k identifikaci či určení totožnosti podepisující osoby. V zásadě jedinou kvalitativní náležitostí je vysoce obecný odkaz na svého druhu zvyklost podepisující osoby připojit „data užívaná $k$ podepsáni“, což mohou být v zásadě jakákoliv data v elektronické podobě. Podrobněji, byt' s odlišnou právní kvalifikací, se problematikou elektronické kontraktace, jakož i jednotlivým náležitostem a funkcím věnovali např. J. Matejka ${ }^{27}$, R. Polčák ${ }^{28}$, F. Korbel s F. Melzerem ${ }^{29}$, K. Čermák ${ }^{30}$, posledně též V. Kment ${ }^{31}$.

\section{DŮKAZNÍ SPOLEHLIVOST PODPISU NA SOUKROMÝCH LISTINÁCH - PRESUMPCE SPOLEHLIVOSTI ZÁZNAMŮ O PRÁVNÍCH JEDNÁNÍCH OBSAŽENÝCH V ELEKTRONICKÉM SYSTÉMU}

S podmínkou písemnosti a písemného projevu vůle pracuje i ustálená česká judikatura ${ }^{32}$, obdobně je v právní praxi pamatováno také dokazování pravosti těchto listin, kde se důsledně vychází z toho, že je na každém, kdo se dovolává soukromé listiny, aby dokázal její pravost a správnost. Je-li soukromá listina použita proti osobě, která listinu zjevně podepsala, nebo proti jejímu dědici nebo proti tomu, kdo nabyl jmění při přeměně právnické osoby jako její právní nástupce, má se za to, že pravost a správnost listiny byla uznána ( $\$ 565$ občanského zákoníku). Z hlediska důkazně procesního tak lze všechny formy elektronických písemností (včetně jejich podpisu) považovat za rovnocenné, resp. ekvivalentní (viz výše), a mohou tedy sloužit jako důkaz ve smyslu všech procesních předpisů českého práva; právní úprava ale obsahuje poměrně netriviální proceduru upravující důkazní spolehlivost některých souvisejících důkazů, a to zejména

27 MATEJKA, J. Úprava elektronického podpisu v právním řádu ČR, Právník, 2001, 4. 5, s. 582-611.

28 POLČÁK, R. Elektronické právní jednání - změny, problémy a nové možnosti v zákoně č. 89/2012 Sb., Bulletin advokacie, 2013, 4. 10, s. 34-40, s. 36, případně též POLČÁK, R. Praxe elektronických dokumentů, Bulletin advokacie, 2011, č. 7-8, s. 55.

29 KORBEL, F. - MELZER, F. Písemnost, elektronický a biometrický podpis v elektronickém právním jednání, Bulletin advokacie, 2014, č. 12, s. 31-6, s. 32.

30 ČERMÁK, K. ml. Elektronický podpis: pohled soukromoprávní. Bulletin advokacie č. 11/2002, s. 64-77.

31 KMENT, V. Nahradí elektronický podpis prostý ten tradiční vlastnoruční? In: Bulletin advokacie, 2016, č. 12, s. 5 .

32 Viz např. Rozsudek Nejvyššího soudu sp. zn. 30 Cdo 1230/2007. 
v ustanovení $§ 565^{33}$ a 566 občanského zákoníku³, kde zákonodárce poněkud nadbytečně hovoří výslovně o pojmu ,soukromá listina“, nikoliv tedy „,soukromá písemnost“, avšak s ohledem na závěry právní doktríny ${ }^{35}$ i ustanovení $§ 3026$ odst. 1 občanského zákoníku ${ }^{36}$, lze dospět k závěru, že se toto ustanovení vztahuje i na soukromé (elektronické) písemnosti.

Z jiného hlediska však lze za klíčové z pohledu důkazní spolehlivosti považovat především ustanovení $§ 562$ odst. 2 větu druhou občanského zákoníku ${ }^{37}$, obsahující jasnou presumpci důkazní spolehlivosti (vyvratitelnou právní domněnku), která reflektuje moderní přístupy k podstatě elektronických písemností a zároveň výrazně usnadňuje užití obvyklých a stále více se vyskytujících forem elektronické kontraktace ${ }^{38}$. Tato cesta zvolená českým zákonodárcem je v mnoha ohledech vhodnější než spoléhat na různé pokusy směřující k zabránění známé erozi důkazní spolehlivosti elektronických písemností tím, že k dokumentu připojujeme další a další autentizační mechanismy (typicky napřr. další kvalifikované podpisy, značka a razítka. Trend elektronického zpracování dokumentů však jednoznačně směřuje k založení jejich důkazní spolehlivosti nikoli prostřednictvím individuálního elektronického podpisu dokumentu, ale prostřednictvím kvalifikované metody a postupu, kterým byl dokument vytvořen nebo kterým je dlouhodobě uložen ${ }^{39}$. Je to tedy elektronický systém, resp. jeho funkční vlastnosti, architektura a design, jež poskytují garance, prostřednictvím nichž presumujeme či následně prokazujeme pravost či autenticitu tam zpracovaných elektronických písemností. Prokáže-li ten, kdo písemností argumentuje, že systém, v němž se písemnost nachází, tyto parametry má, přesouvá se důkazní břemeno na toho, kdo tvrdí nedostatek její pravosti.

Elektronické písemnosti tak mají z hlediska svého významu, možností použití i samotné právní síly, v zásadě ekvivalentní postavení jako jiné tradiční formy, včetně forem listinných (typicky papírových nosičů záznamu) ${ }^{40}$. Tato ekvivalence listinné

33 Je na každém, kdo se dovolává soukromé listiny, aby dokázal její pravost a správnost. Je-li soukromá listina použita proti osobě, která listinu zjevně podepsala, nebo proti jejímu dědici nebo proti tomu, kdo nabyl jmění při přeměně právnické osoby jako její právní nástupce, má se za to, že pravost a správnost listiny byla uznána.

34 (1) Není-li soukromá listina podepsána, je na tom, kdo ji použil, aby dokázal, že pochází od osoby, o níž to tvrdí. (2) Má se za to, že písemnosti týkající se právních skutečností, k nimž dochází při běžném provozu závodu, dokazují, dovolává-li se jich druhá strana k svému prospěchu, co je v listině obsaženo a že listina byla vystavena v době na ní uvedené; to platí i v př́ípadě, že listina nebyla podepsána.

35 Viz např. MATEJKA, J. Úprava elektronického podpisu v právním řádu ČR, Právník, 2001, č. 5, s. $582-611$.

36 Nevylučuje-li to povaha písemnosti, platí ustanovení tohoto zákona o listině obdobně i pro jinou písemnost bez zřetele na její podobu.

37 Má se za to, že záznamy údajů o právních jednáních v elektronickém systému jsou spolehlivé, provádějí-li se systematicky a posloupně a jsou-li chráněny proti změnám. Byl-li záznam pořízen při provozu závodu a dovolá-li se jej druhá strana k svému prospěchu, má se za to, že záznam je spolehlivý.

$38 \mathrm{~K}$ tomu vice viz např. MASON, S. Electronic Signatures in Law. Cambridge University Press, Cambridge, 2012, s. 259.

$39 \mathrm{~K}$ tomu více viz POLČÁK, R. Elektronické právní jednání: změny, problémy a nové možnosti v zákoně č. 89/2012 Sb. Bulletin advokacie, 2013, č. 10, s., 34 40. Dostupný také na: <http://www.bulletin-advokacie .cz/elektronicke-pravni-jednani-zmeny-problemy-a-nove-moznosti-v-zakone-c.-892012-sb>, případně též VOLAREVIC, M. - STRASBERGER, V. - PACELAT, E. A philosophy of the electronic document management, in Information Technology Interfaces. Pula: IEEE, s. 141.

40 Uveden princip tak nepřímo akcentuje mimo jiné ustanovení § 2 písm. e) zákona č. 499/2004 Sb., o archivnictví a spisové službě, podle nějž se dokumentem rozumí každá písemná, obrazová, zvuková nebo jiná zaznamenaná informace, at' již v podobě analogové či digitální. 
a elektronické formy tak má v mnoha ohledech výrazně širší dopady, než jen na písemnosti, nebot' se po právní stránce týká nejen písma, ale i obrazu, zvuku či jiných záznamů; limitem tak zde nebudou právní omezení jejich použitelnosti, ale především existující technické možnosti záznamu na papír. ${ }^{41}$

\section{BEHAVIORÁLNÍ FORMY - BIOMETRICKÝ PODPIS}

S ohledem na použitou technologii lze hovořit o celém spektru dalších možných variant elektronického podepisování. Obvykle ale půjde o odvozeniny podpisů elektronických, přičemž odlišujícím kritériem bude obvykle způsob použitého autentizačního mechanismu (vzorku), př́ípadně míra kvality zabezpečení, použité technologie, př́ípadně záruk třetích stran (typicky certifikačních autorit).

Právě z pohledu použitých autentizačních, resp. identifikačních mechanismů je vhodné uvést zejména široké možnosti autentizace prostřednictvím behaviorální biometrických znaků člověka (např. dynamiky záznamu řeči, chůze, psaní na klávesnici, apod.). Typickým projevem tohoto př́stupu představuje tzv. dynamický biometrický podpis, který činí podpisující osoba vlastní rukou, avšak nikoli na listinu, nýbrž na vysoce citlivé zařizení (tablet), které digitálně zaznamenává nejen konkrétní podobu samotného (vlastnoručního) podpisu, ale i celou řadu další údajů, včetně tvaru opsané křivky, dynamiku polohy pera, celkové i etapové rychlosti, fragmentového zrychlení, přítlaku po celou dobu vedení pera, apod. Kombinace všech uvedených charakteristik v rámci dynamického biometrického podpisu je pak natolik unikátní a specifická pro konkrétní osobu, že ji může s dostatečnou přesností identifikovat, přičemž z tohoto důvodu představuje vysoce atraktivní formu autentizace. ${ }^{42}$ Tyto údaje (charakteristiky) jsou v závislosti na použité technologii zaznamenány do digitálního souboru (datové zprávy), který z pohledu platné právní úpravy splňuje náležitosti (prostého) elektronického podpisu.

Uvedené ustanovení je klíčové z hlediska samotné důkazní spolehlivosti moderních forem podpisu, a to včetně tzv. dynamického biometrického podpisu (viz výše). Vezmeme-li v úvahu, že tato technologie podpisu v nějaké své fázi musí shromažd'ovat biometrické charakteristiky podepisující se osoby (lhostejno zda oprávněně s jejím vědomím, př́ípadně neoprávněně pod nepravdivou záminkou), nelze vyloučit, že tato data mohou být v budoucnosti zneužita pro vytvoření dalších odvozenin původního podpisu.

41 Ani občanského zákoníku tak v zásadě zásadně nepreferuje výrazně listinu před jinými formami písemností, např. dle $\S 3026$ odst. 1 platí všechna ustanovení zákoníku o listinách i pro jiné písemnosti bez zřetele na jejich podobu (formu), to však jen za předpokladu, že to nevylučuje povaha písemnosti. Povaha písemnosti to např. bude vylučovat u holografních listin, kde se vyžaduje, aby byla skutečně ručním písmem napsána jednajícím, nikoli vytvořená prostředky ICT.

Viz např. tradiční požadavek vlastnoručního podpisu u závěti v § 1533 nebo obdobný, ale zcela zbytečný požadavek u hlasování vlastníků jednotek při rozhodnutí shromáždění vlastníků jednotek mimo zasedání dle $\S 1212$ ).

42 Nutno však pro úplnost uvést, že ačkoliv právě z těchto důvodů tento druh podpisu zavádí do praxe celá řada osob, včetně typu bank, mobilních operátorů, přepravců atd., ze strany podepisující osoby nejde o vlastnoruční podepisování v právním slova smyslu, ale pouze o formu autentizace vázané na odběr konkrétní dynamické charakteristicky konkrétní osoby. 
Biometrické podpisy totiž existují „samy o sobě“a nezávisí na podepsaném dokumentu. V principu tedy nelze vyloučit, aby byly z původních elektronických písemností odňaty a připojeny $\mathrm{k}$ jiným písemnostem. ${ }^{43}$

Pro praktické využití biometrických podpisů k podepisování elektronických dokumentů proto potřebujeme nějakou „dostatečně spolehlivou a pevnou“ vazbu mezi samotným podpisem a dokumentem. Takovou, kterou by nešlo zpřetrhat, a která okamžitě odhalí jakoukoli manipulaci (změnu dokumentu či samotného podpisu). Tyto postupy jsou však s ohledem na rozvoj neuronových sítí (umělé inteligence) stále více netriviální; lze však jít cestou jejich propojení s metodami asymetrické kryptografie (viz níže), kde se k podepisovanému dokumentu připojí získaná biometrická data (dynamický biometrický podpis), a výsledný podpis následně systém podepíše svým kvalifikovaným elektronickým podpisem. ${ }^{44}$

Právě tyto skutečnost představuje patrně zásadní nevýhodu výrazně limitující či alespoň omezující další rozvoje a použití této (behaviorální) kategorie podpisu, a to včetně pracovněprávních vztahů, kde lze ochranu souvisejících osobních údajů považovat za zásadní atribut realizace těchto vztahů. ${ }^{45}$

\section{DORUČOVÁNÍ PROSTŘEDNICTVÍM INFORMAČNÍHO SYSTÉMU DATOVÝCH SCHRÁNEK}

Informační systém datových schránek (ISDS) představuje zvláštní systém elektronického úložišstě určeného k doručování elektronických dokumentů od orgánů veřejné moci a k provádění úkonů vůči orgánům veřejné moci a dodávání dokumentů fyzických i právnických osob mezi sebou. Tento systém byl založen zákonem č. 300/2008 Sb., o elektronických úkonech a autorizované konverzi dokumentů (ZoSVD), jež nabyl účinnosti dne 1. července 2009. Tento zákon svou koncepcí narušuje a zásadně mění dosavadní způsoby činností orgánů veřejné moci př̀i uskutečňování písemných právních úkonů. Tímto nastává faktické přerušení zažitých mnohdy více jak sto let trvajících principů, metod „listinného“ fungování české veřejné správy, jejíž kořeny a historie sahají do první poloviny 18 . století. Zákon tak lze označit za určitý právní milník 21. století, století, ve kterém dochází k jednotné „elektronizaci“ orgánů

43 Viz. MATEJKA, J. - GÜTTLER, V. Electronic Written Documents and Biometric Options of Their Signing - Problem of Evidentiary Reliability and Personal Data Protection. In: The Lawyer Quarterly, 2018, roč. 8 , č. 1 , s. $38-50$.

44 Uvedená procedura však klade velmi vysoké nároky na kvalitu a funkční vlastnosti př́ílušných systémů, navíc zde přibývá nutností sofistikovaného vyhodnocení biometrických údajů (vůči podpisovému vzoru), a tedy i dalšího potenciálního ohrožení celého systému (možnost zneužití databáze podpisových vzorů), apod. Tyto aspekty však nebyly dosud uspokojivě řešeny. K tomu více viz PETERKA, J. Elektronický podpis na rozcestí. [online] [cit. 28. 12. 2011]. Dostupné na: <http://www.lupa.cz/clanky/elektronicky-podpis-na-rozcesti>.

$45 \mathrm{~K}$ tomu více viz $\mathrm{K}$ problematice lidských práv se zřetelem $\mathrm{k}$ biometrice více viz GÜTTLER, $\mathrm{V}$. MATEJKA, J. K otázkám některých základních lidských práv a svobod v souvislosti s právní ochranou biometrických údajů. Právník, 2016, roč. 155, č. 12, s. 1055, dále též viz MATEJKA, J. - GÜTTLER, V. Electronic Written Documents and Biometric Options of Their Signing - Problem of Evidentiary Reliability and Personal Data Protection. In: The Lawyer Quarterly, 2018, roč. 8, č. 1, s. 38. 
veřejné moci ČR. Zákon tak ve svém důsledku představuje jeden z nejvýznamnějších předpisů regulujících právní vztahy v prostředí české informační společnosti. Nutno pro úplnost uvést, že ČR je v podstatě prvním státem na světě, kde je používání datové schránky pro orgány veřejné moci a podnikající subjekty v režimu zákona obligatorní. V Evropě obdobný informační systém funguje např́íklad v Dánsku a Rakousku, v Německu je podobný systém připravován. Evropská unie zatím takovýto komunikační kanál nemá, ale $\mathrm{v}$ budoucnu jistě bude podobný komunikační nástroj potřebovat ${ }^{46}$. Za hranicemi Evropského kontinentu, konkrétně ve Spojených státech amerických, je obdobný systém využíván v Kalifornii pro komunikaci mezi veřejnou správou a velkými korporacemi ${ }^{47}$.

Datová schránka je podle $\S 2$ zákona elektronickým úložištěm, které je určeno k dvěma účelům a to: a) doručování orgány veřejné moci, b) provádění úkonů vůči orgánům veřejné moci. Dne 1. 1. 2010 přibyl i třetí účel, a to dodávání dokumentů fyzických osob, podnikajících fyzických osob a právnických osob. Samotná elektronická komunikace pomocí datové schránky je realizována prostřednictvím tzv. datové zprávy, která představuje elektronická data, jež lze přenášet prostředky pro elektronickou komunikaci a uchovávat je na záznamových médiích používaných při zpracování a přenosu dat elektronickou formou ${ }^{48}$. Datovou zprávu tvoří obálka a obsah zprávy, přičemž obsahem zprávy může být jedna či více př́loh v povoleném datovém formátu. Dokument, který byl dodán ${ }^{49}$ resp. odeslán do datové schránky, je doručen okamžikem, kdy se do datové schránky přihlásí osoba, která má s ohledem na rozsah svého oprávnění přístup $\mathrm{k}$ dodanému resp. doručenému dokumentu. Takovouto osobou bude zejména primární uživatel datové schránky tj. osoba, které byla datová schránka zřízena anebo též i soba pověřená či administrátor. Je důležité upozornit, že doručení dokumentu zmíněným způsobem má stejné právní účinky jako doručení do vlastních rukou. ${ }^{50}$

Ustanovení § 18 odst. 2 ZoSVD pak obsahuje zvláštní úpravu podpisu, resp. přesněji jeho domněnky; zákon zde stanoví, že úkony učiněné primárním uživatelem datové schránky, tzn. úkony jako podání, návrhy, podněty, žádosti, atp., př́ípadně též administrátorem anebo pověřenou osobou, mají stejné účinky jako úkony učiněné písemně a podepsané, ledaže jiný právní předpis nebo vnitřní předpis požaduje společný úkon více z uvedených osob. ${ }^{51}$

46 IDNES.Cz. On-line rozhovor. Chýlek, P., a Stiegler, P., [online] [cit. 19. 11. 2009].

47 Loebl., Z. Datové schránky v justici? Nevěřím, že budou v praxi fungovat. [cit. 18. 8. 2009] Dostupné online na: $<$ http://www.ejustice.cz/zbynek-loebl-datove-schranky-v-justici-neverim-ze-budou-v-praxi -fungovat $>$.

48 K tomu srovnej definici elektronického podpisu uvedenou v § 2 zákona č. 227/2000 Sb., o elektronickém podpisu, v platném znění.

49 Zákon přitom volí slovo „dodán“ namísto „doručen“ či „,zaslán“.

50 Na doručování dokumentů mezi orgány veřejné moci prostřednictvím datové schránky se vztahují dvě omezení. Prvním omezení vyplývá z předmětu zákonné úpravy, kde je stanoveno, že Zákon se nevztahuje na dokumenty, které obsahují utajované informace. Druhým omezením jsou důvody bezpečnostního charakteru, nebot' doručování mezi orgány veřejné moci prostřednictvím datové schránky se nepoužije, pokud je z bezpečnostních důvodů mezi těmito orgány zavedena jiná forma elektronické komunikace.

51 Obecně však není dána povinnost jednající osoby resp. osoby činící úkon prostř̌ednictvím datové schránky použivat zaručený elektronický podpis. 


\section{ZÁVĚR}

Jak bylo stanoveno v úvodu tohoto článku, současná pracovněprávní úprava realizace významných pracovněprávních úkonů (ve smyslu § 334 odst. 2 zákoníku práce) nepočitá díky zvláštní úpravě jejich doručování a své relativní komplexnosti s tím, že by elektronické pracovněprávní písemnosti mohly být doručovány (či přesněji realizovány) i jiným způsobem než výhradně jen prostřednictvím služby či sítě elektronických komunikací. $Z$ důvodu ochrany slabší strany kontraktačního procesu (zaměstnance) tak př́mo nepočítá s možností tzv. osobního doručení elektronické písemnosti např. formou jejího osobního předání, případně s jinými variantami, které jsou s ohledem na svou podstatu důkazně spolehlivější než je tradiční forma doručování listinných písemností v podobě tzv. předání „,Z ruky do ruky“, případně nesrovnatelně spolehlivější z pohledu výsledného stvrzení těchto úkonů tradičním vlastnoručním podpisem obou smluvních stran.

Jde zejména o standardní možnosti realizace těchto pracovněprávních jednání formou elektronického podpisu dle eIDAS, resp. jeho vyšší (uznávaných) variant, př́ípadně elektronických variant podpisů založených na biometrické (behaviorální) autentizaci podepisující osoby, kde lze současné zákonné požadavky kladené na jejich doručování považovat za nepřiléhavé a v zásadě i ohrožující všechny moderní formy elektronického právního styku. Pracovněprávní úprava tak rovněž nereflektuje související možnosti vyplývající ze shora uvedené domněnky spolehlivosti elektronických záznamů stanovící, že záznamy údajů o právních jednáních v elektronickém systému jsou spolehlivé, provádějí-li se systematicky a posloupně a jsou-li chráněny proti změnám (§562 odst. 2 občanského zákoníku). Lze jistě namítnout, že současná právní úprava výslovně nevylučuje řešit uvedené určitou odchylnou úpravou ve smyslu ustanovení § 4a zákoníku práce, případně formou systematického extensivního výkladu pojmu „do vlastních rukou“ či jinou formou argumentace „e ratione legis“, př́ípadně pomocí výkladových pravidel upravených v občanském zákoníku ${ }^{52}$; výsledek takové interpretace by však s ohledem na jeho následnou aplikaci nemusel v současnosti poskytovat dostatečnou míru právní jistoty.

Navzdory relativně rigidní a omezující podobě současného pracovního práva však nutno připomenout, že je zde minimálně velmi sporně naplňován princip obsažený v čl. 25 odst. 1 prrímo použitelného nařízení eIDAS, podle kterého nesmějí být elektronickému podpisu upírány právní účinky a nesmí být odmítán jako důkaz v soudním a správním ř́zzení pouze z toho důvodu, že má elektronickou podobu nebo že nesplňuje

\footnotetext{
$52 \mathrm{~K}$ tomu např. srovnej ustanovení $\S 2$ odst. 1 občanského zákoníku „Každé ustanovení soukromého práva lze vykládat jenom ve shoděs Listinou základnich práv a svobod a ústavním pořádkem vi̊bec, se zásadami, na nichž spočivá tento zákon, jakož is trvalým zřetelem k hodnotám, které se tím chrání. Rozejde-li se výklad jednotlivého ustanovení pouze podle jeho slov s tímto př́kazem, musi mu ustoupit.“, prípadně též výkladové pravidlo upravené v ustanovení § 20 zákoníku práce „Je-li možné právní jednání vyložit ruozným zpưsobem, použije se výklad pro zamèstnance nejpřiznivějšsi. “"
} 
požadavky na kvalifikované53 elektronické podpisy ${ }^{54}$; lze jistě souhlasit s tezí, že jedním z účelů zákonem požadované písemné formy, resp. naplnění souvisejících požadavků na jejich doručování, je mimo jiné55 určitá varující funkce, případně s ohledem na význam konkrétního jednání také funkce důkazní, což však vhodná varianta podpisu dle eIDAS splňuje.

Všechny shora uvedené skutečnosti nutno zejména zohlednit při použití všech moderních prvků kontraktace, kde musí být dostatečně akcentována především skutečnost, že moderní pracovní právo nemůže rezignovat na své ochranné působení; je tedy třeba hledat vždy taková řešení, která zohlední jak potřebu užívání moderních kontraktačních nástrojů, tak i nutnost garantovat minimální ochranu slabší strany pracovněprávního vztahu.

Má-li být kontraktace prostřednictvím těchto moderních forem efektivní, je třeba při jejich aplikaci důsledně vycházet $\mathrm{z}$ historicky osvědčených a ustálených zásad a principů soukromého práva, včetně zvyklostí práva pracovního. Samotné elektronické formy podepisování ve formě připojení biometrických (fyzických či behaviorálních) dat k elektronickým písemnostem (právním jednáním), tak nejenom že důsledně navazují na toto tradiční (tj. především grafické) pojetí podpisu, ale zároveň představují zdánlivě ideální propojení tradičního a elektronického pojetí podepisování směřující $\mathrm{k}$ tolik žádoucímu přirozenému rozvoji práva. Připuštění možnosti užití těchto moderních forem podpisu tak v mnoha ohledech posiluje jak postavení elektronických písemností a jejich využití v právním styku, tak i zcela nepochybně povede ke standardizaci nových praktických postupu kombinujících metody biometrické (jako ideální autentizační či kvasi-identifikační nástroj) a kryptologické (kvalifikovaný elektronický podpis). Lze však přistoupit pouze $\mathrm{k}$ takovým změnám, které budou ve svých celkových souvislostech představovat úpravu komplexní, tedy úpravu, jež nebude nedůvodně diskriminovat osvědčené nástroje elektronické kontraktace a zároveň bude respektovat jak ochrannou, tak i organizační funkci pracovního práva, nebot' jen splnění všech těchto podmínek může garantovat vyváženou, stabilní a především moderní právní úpravu.

JUDr. Ján Matejka, Ph.D.

Ústav státu a práva AV ČR, v. v. i.

matejka@ilaw.cas.cz

53 Kvalifikovaný elektronický podpis má právní účinek rovnocenný vlastnoručnímu podpisu (čl. 25 odst. 2 nařízení eIDAS).

54 Rovněž i z odůvodnění nařízení eIDAS (čl. 48 a násl.) stanoví, že k zajištění vzájemného uznávání elektronických podpisů je sice zapotřebí vysoká úroveň bezpečnosti, nicméně měly by být ve zvláštních př́ípadech, napríklad v kontextu rozhodnutí Komise 2009/767/ES 10), přijímány rovněž elektronické podpisy s nižší zárukou bezpečnosti.

55 Jen výjimečně jsou plněny i další funkce, např. zajištění právní jistoty třetích stran ve formě dispozice s věcnými právy $\mathrm{k}$ nemovité věci dle $§ 560$, apod. 